\title{
Germline mutational analysis of presenilin 1 and APP genes in Jewish-Israeli individuals with familial or early-onset Alzheimer disease using denaturing gradient gel electrophoresis (DGGE)
}

\author{
H aike R eznik-Wolf ${ }^{1}$, Therese A Treves ${ }^{2}$, Herzel Shabtai ${ }^{2}$, Judith A haron-Peretz ${ }^{3}$, \\ Joab Chapman ${ }^{2}$, M ichael Davidson ${ }^{4}, G$ ad Barkai ${ }^{1}$, Peter H St G eorge Hyslop ${ }^{5}$, \\ Boleslaw Goldman ${ }^{1}$, A mos D Korczyn ${ }^{2}$ and E itan Friedman ${ }^{1}$ \\ ${ }^{1}$ Institute of G enetics; ${ }^{4} \mathrm{~A}$ Izheimer's disease clinic; ${ }^{2}$ Sheba M edical Center, Tel-H ashomer, D epartments of N eurology, \\ Elias Sourasky Medical Center, Tel-A viv \\ ${ }^{3} \mathrm{R}$ ambam M edical Center, $\mathrm{H}$ aifa, Israel \\ ${ }^{5} \mathrm{D}$ epartment of N eurology, Center for Research into N eurodegenerative D isorders, Toronto, Canada
}

\begin{abstract}
Germ line mutations in three genes have been detected in patients with familial Alzheimer's disease (FAD) and sporadic, early onset disease: amyloid precursor protein (APP), presenilin 1 (PS-1), and presenilin 2 (PS-2). The relative proportions in which mutations in these genes occur among AD patients in Israel has not been evaluated. To that end, we screened 52 Jewish-Israeli patients with AD: 22 with sporadic, early-onset disease (below 65 years), and 30 with FAD. Mutation screen employed denaturing gradient gel electrophoresis (DGGE) of exon-specific PCRs and restriction enzyme digest. Five patients from three different families displayed mutations within the PS-1 gene: three patients of one family showed a mis-sense mutation in codon 120 (Glu 120Lys), and two other unrelated patients showed an identical mis-sense mutation in codon 318 (Glu318Gly). No patient showed an abnormal migration on DGGE (for APP) or mutant restriction digest pattern (for PS-2) genes. These data may indicate the existence of another familial Alzheimer disease (FAD) gene locus in the Israeli Jewish population.
\end{abstract}

Keywords: Alzheimer's disease; genetic predisposition; mutation analysis

\section{Introduction}

A Izheimer disease (AD), is a neurodegenerative disease affecting up to $15 \%$ of the octogenarian popula-

Correspondence: E itan Friedman, Chief, The Susanne Levy O ncogenetics L aboratory, Institute of G enetics, Chaim Sheba M edical Center, Tel-H ashomer, 52621, I srael

R eceived 17 A pril 1997; revised 170 ctober 1997; accepted 22 O ctober 1997 tion. ${ }^{1}$. The $\varepsilon 4$ allele of the APOE gene has been associated with increased $A D$ risk. ${ }^{2} A$ subset of $A D$ patients has a family history of the disease, where inheritance follows an autosomal dominant pattern and at times, early age at onset (under 65), with three identified genes involved in familial AD predisposition. A handful of germ line mutations occur within exons 16 and 17 of the amyloid precursor protein (A P P) gene on chromosome $21 .^{3-6} \mathrm{G}$ ermline mutations in presenilin 1 
(PS-1), on chromosome $14^{7}$ presumably account for the majority of familial and early onset $A D{ }^{8}$ with more than 30 different mis-sense mutations reported in ethnically diverse $A D$ families. ${ }^{8-13}$ Finally, in a well defined population of Volga Germans, a single missense mutation ( $\mathrm{N} 141 \mathrm{l}$ ) within presenilin 2 (PS-2) on chromosome 1 accounts for the majority of phenotypically affected individuals. ${ }^{14,15}$ A necdotal reports of germ line mutation in PS-1 in Jewish FA D patients ${ }^{9,16}$ were reported, but no systematic characterization of germ line mutations in these genes in Jewish FAD patients was published. To that end, we screened 52 J ewish-I sraeli patients with either early-onset or FA D for mutations within these genes, using denaturing gradient gel electrophoresis (DGGE), and restriction enzyme digest. In addition, APOE genotype was determined in the same population. (Tables la and Table 1b.)

\section{Materials and Methods}

Clinical Characteristics

Fifty-two patients from 49 families formed the basis of this study, which was approved by the $\mathrm{H}$ uman $\mathrm{E}$ thics Committee. A II participants had A D based on standard, accepted criteria. ${ }^{17,18}$ Early-onset and familial AD were diagnosed, if clinical diagnosis of AD with exclusion of other causes of dementia, ${ }^{19}$ with onset of symptoms prior to age 65 , or at least one additional first degree relative with $A D$, respectively.

\section{Mutation Analysis and Allelic Determination}

DNA extracted from peripheral blood leukocytes using standard protocols, served as a template in the polymerase chain reaction (PCR). The final reaction volume was $50 \mu \mathrm{l}$ (except for APOE genotyping of $25 \mu \mathrm{l}$ ), containing the standard PCR components. The primers used in DGGE analysis (PS-1 and APP) were based on the melting profiles, ${ }^{20}$ predicting that the amplified fragment region of interest would be contained in a single, low-melting domain, increasing the likelihood of mutation detection.

B etween 100 and $250 \mathrm{ng}$ of DNA were used per $P C R$, or in the case of 'nested PCR', 3-5 $\mu$ l of the 'outer PCR'. Thermal cycling was achieved in a PTC 100-60 thermocycler (M.J. R esearch, Watertown, M A ). A n initial $94^{\circ} \mathrm{C}$ denaturation step for $5^{\prime}$ was followed by 30 cycles of denaturation at $94^{\circ} \mathrm{C}\left(1^{\prime}\right)$, annealing at a temperature of $52-66^{\circ} \mathrm{C}$ and extending to $72^{\circ} \mathrm{C}$ (1'), with a final extension step of $5^{\prime}$ at $72^{\circ} \mathrm{C}$. The cycling profiles and PCR conditions are available. All products ( $5 \mu \mathrm{l} /$ reaction), were analysed on a $2 \%$ agarose gel.

Of the PCR products of the PS-2 gene or APOE $10 \mu$ l were subjected to a Sau3A or $\mathrm{H}$ hal digest respectively ( $\mathrm{New}$ E ngland Biolabs) at $37^{\circ} \mathrm{C}$ overnight, and were run on a $2 \%$ or $8 \%$ polyacrylamide gel respectively, at $250 \mathrm{~V}$ for 2 hours, and visualized with ethidium bromide.

Parallel denaturing gradient gels were cast and run using the $\mathrm{H}$ offer Scientific instruments model SE 620 (San Francisco, CA ) as described. ${ }^{21}$ The optimal denaturant range
Table la Clinical details on familial A D patients

\begin{tabular}{|c|c|c|c|c|}
\hline $\begin{array}{l}\text { Patient } \\
\text { no. }\end{array}$ & Origin & Sex & $\begin{array}{l}\text { A ge at } \\
\text { onset }\end{array}$ & $\begin{array}{l}\text { A dditional affected first } \\
\text { degree family members }\end{array}$ \\
\hline 1 & Libya & Female & 40 & - \\
\hline $2 *$ & Romania & Female & 43 & Two more siblings \\
\hline 3 & G ermany & Female & 44 & - \\
\hline 4 & Romania & Female & 44 & - \\
\hline $5^{*}$ & R omania & Male & 45 & Two more siblings \\
\hline 6 & Iran & Female & 47 & - \\
\hline 7 & R ussia & M ale & 48 & - \\
\hline 8* & Romania & Male & 48 & Two more siblings \\
\hline 9 & Yemen & Female & 51 & - \\
\hline 10 & A shkenazi & Female & 53 & - \\
\hline 11 & Poland & Female & 53 & - \\
\hline 12 & E gypt & M ale & 54 & - \\
\hline $13^{*}$ & Romania & Female & 55 & - \\
\hline 14 & A shkenazi & M ale & 55 & - \\
\hline 15 & E gypt & Female & 57 & - \\
\hline 16 & Poland & Female & 58 & - \\
\hline 17 & Lebanon & Female & 58 & - \\
\hline 18 & Sephardic & $M$ ale & 59 & - \\
\hline 19 & Iraq & $M$ ale & 60 & - \\
\hline 20 & R omania & Female & 62 & - \\
\hline 21 & Poland & Female & 64 & - \\
\hline 22 & Romania & Female & 66 & - \\
\hline 23 & A shkenazi & Female & 67 & - \\
\hline 24 & Poland & Male & 68 & - \\
\hline 25 & G ermany & M ale & 70 & - \\
\hline 26 & Poland & M ale & 72 & - \\
\hline 27 & R omania & M ale & 72 & - \\
\hline 28 & A shkenazi & Female & 78 & Two brothers \\
\hline 29 & Poland & Female & 78 & Two sisters \\
\hline 30 & Poland & Female & 80 & - \\
\hline
\end{tabular}

*D enotes a mutation carrier; age at disease onset was based on standard criteria: clinical and objective diagnosis of $A D$, exclusion of other reasons for dementia, with onset of symptoms prior to age 65 or at least one additional first degree relative with $A D$. Whenever the origin is $A$ shkenazi both parents originated from East-European countries. Sephardic, non-A shkenazi origin. From each family, only one individual was tested, and all testees were unrelated to each other.

yielding focused bands for the APP and PS-1 genes are summarized in Table 2.

Of the PCR reaction, $20 \mu$ l were loaded onto the gel and, following electrophoresis for 16 hours at 80 volts or 3-4 hours at 160 volts (Table 2 ) in $60^{\circ} \mathrm{C}$ on $7 \%$ denaturing acrylamide gel, the gels were silver stained. DNA sequencing was performed using a biotinylated primer, as previously described. $^{22}$

\section{Results}

Patient Characteristics

Fifty-two patients (22 men, 30 women) were analysed. Thirty cases (11 men, 19 women) were designated as familial if there was at least one additional first degree 
Table $\mathbf{1 b}$ Clinical details on sporadic early onset AD patients

\begin{tabular}{|c|c|c|c|}
\hline $\begin{array}{l}\text { Patient } \\
\text { no. }\end{array}$ & Origin & Sex & $\begin{array}{l}\text { A ge at } \\
\text { onset }\end{array}$ \\
\hline 1 & E gypt & Male & 42 \\
\hline 2 & Buchara & Female & 45 \\
\hline 3 & Slovania & Female & 50 \\
\hline 4 & Poland & Female & 51 \\
\hline 5 & South A frica & Female & 52 \\
\hline 6 & A shkenazi & Female & 53 \\
\hline $7 *$ & Morocco & Male & 55 \\
\hline 8 & South A frica & Female & 55 \\
\hline 9 & A shkenazi & Male & 55 \\
\hline 10 & E gypt & Male & 56 \\
\hline 11 & Turkey & Male & 56 \\
\hline 12 & Iran & Male & 56 \\
\hline 13 & M orocco & Male & 56 \\
\hline 14 & A shkenazi & Male & 57 \\
\hline 15 & Tunisia & Male & 59 \\
\hline 16 & A shkenazi & Female & 60 \\
\hline 17 & A shkenazi & Female & 60 \\
\hline 18 & Morocco & Female & 61 \\
\hline 19 & Poland & Female & 61 \\
\hline 20 & A shkenazi & Male & 63 \\
\hline 21 & Poland & Male & 63 \\
\hline 22 & U zbekistan & Female & 63 \\
\hline
\end{tabular}

*D enotes a mutation carrier; age at disease onset was based on standard criteria: clinical and objective diagnosis of AD with onset of symptoms prior to age 65 . Whenever the origin is A shkenazi, both parents originated from East-E uropean countries.

Table 2 D G GE conditions for running PCR fragments

\begin{tabular}{|c|c|c|c|c|}
\hline G ene & Exon no. & $\begin{array}{l}\text { Denaturant } \\
\text { range }(\%)\end{array}$ & $\begin{array}{l}\text { Running time } \\
\text { (h) }\end{array}$ & Voltage \\
\hline$\overline{A P P}$ & $\begin{array}{l}16 \\
17\end{array}$ & $\begin{array}{l}20-60 \\
30-70\end{array}$ & $\begin{array}{l}3.5 \\
3.5\end{array}$ & $\begin{array}{l}160 \mathrm{v} . \\
160 \mathrm{v} .\end{array}$ \\
\hline PS-1 & $\begin{array}{l}3 \\
4 a \\
4 b \\
5 \\
6 \\
7 a \\
7 b \\
8 \\
9 a \\
9 b \\
10 \\
11 \\
12\end{array}$ & $\begin{array}{l}20-80 \\
40-70 \\
45-85 \\
35-75 \\
20-80 \\
20-80 \\
35-75 \\
25-55 \\
35-75 \\
30-50 \\
35-75 \\
20-80 \\
20-80\end{array}$ & $\begin{array}{l}\text { ON } \\
2.75 \\
O N \\
O N \\
O N \\
O N \\
O N \\
3.0 \\
O N \\
O N \\
O N \\
O N \\
O N\end{array}$ & $\begin{array}{r}80 \mathrm{v} . \\
160 \mathrm{v} . \\
80 \mathrm{v} . \\
80 \mathrm{v} . \\
80 \mathrm{v} . \\
80 \mathrm{v} . \\
80 \mathrm{v} . \\
160 \mathrm{v} . \\
80 \mathrm{v} . \\
80 \mathrm{v} . \\
80 \mathrm{v} . \\
80 \mathrm{v} . \\
80 \mathrm{v} .\end{array}$ \\
\hline
\end{tabular}

*D enotes an overnight run, which typically lasts 15-18 hours.

family member with probable A D. A ge range at disease onset for these patients was 40-80 years (median 58). The rest ( 11 men, 11 women) were sporadic, early onset cases (disease onset prior to age 65), and the age range was 42-63 years (median 56), with five patients between 60 and 65 years old. There were 32 patients of
A shkenazi (E ast E uropean) origin and 20 non-A shkenazis (Table 1 ).

\section{Mutation Analyses and APOE Genotypes}

Of 52 patients, 47 did not display any D G GE migration abnormalities in the 10 coding exons PS- 1 . Three patients from a single A shkenazi family were found to carry a mis-sense mutation G lu120Lys. ${ }^{16}$ Two additional patients, one A shkenazi and one M oroccan, displayed migration abnormalities in exon 9 in the PS-1 gene (Figure 1a). Direct DNA sequencing showed a missense mutation: $A$ to $G$ change at codon 318 altering G lutamine to glycine (Figure $1 b$ ).

No patient showed any abnormal migration pattern on DG GE in exons 16 and 17 of the APP gene, whereas a known mutation in exon 16 (K 670N/M 671L ) ${ }^{23}$ was easily detected (Figure 2). Furthermore, no patient displayed the N 141I mutation of the PS-2 gene.

APOE genotyping revealed E $3-66.6 \%$, E $4-25 \%$ and $E 2-8.3 \%$ for the familial cases, and E $3-77.2 \%$, E $4-20.4 \%$ and E2 - 2.2\% for the sporadic cases. N otably, two patients were homozygous for the A POE 4 allele - one familial case (age at onset 70 years) and a sporadic case (age - 53 years).

\section{Case Reports of Patients Displaying PS-1 mutations}

The clinical details of the G IU120G ly mutation carriers have been previously reported, ${ }^{16}$ and an identical mutation has independently been reported. ${ }^{10}$ Two patients carried an identical mutation in codon 318 of the PS-1 gene (G lu318G ly). O ne is a J ewish-M oroccan male, with slow progressive dementia starting at age 55 . Notably, no cases of AD in his family were reported, and his parents died of cancer at 67 (mother) and 72 (father) years of age. The second mutation carrier is a J ewish-R omanian woman, in whom progressive memory impairment started at age 55 , with depression being the predominant accompanying manifestation and slow progression of cognitive dysfunction over a 10-year period. The patient's father who died at 84 years suffered from dementia starting at his late seventies.

\section{Discussion}

In this study we screened for germ line mutations in three genes known to be associated with $A D$ predisposition in 52 patients with FAD or early-onset $A D$, representing 49 families, and only five patients from 
(A)

\section{$30-50 \%$}
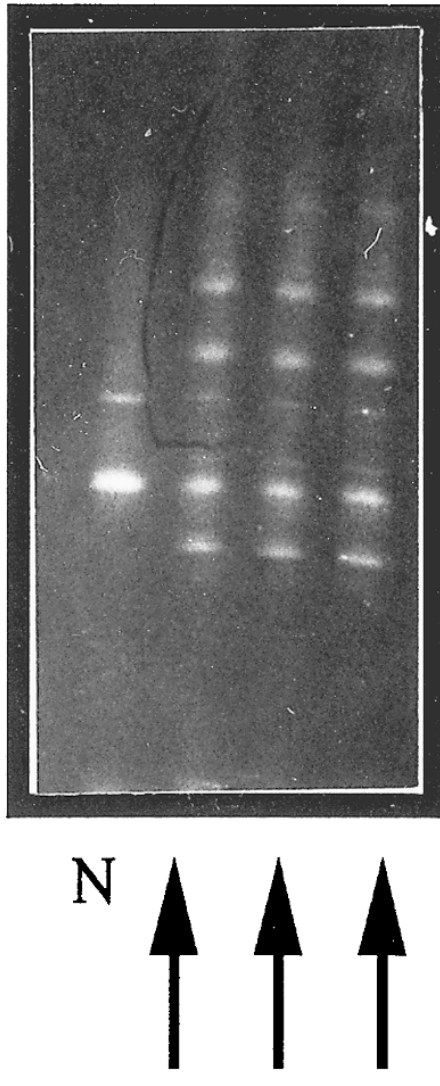

(B)

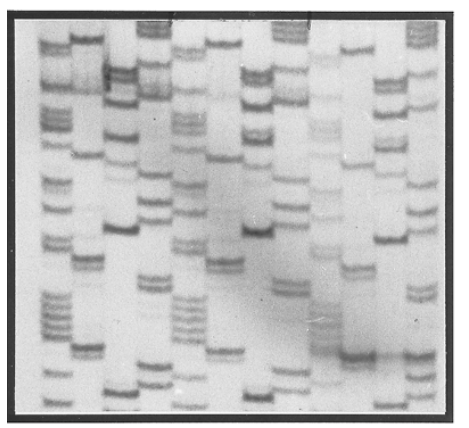

\section{codon 318}

GAA $=>$ GGA

normal mutant mutant

Figure la D enaturing gradient gel electrophoresis ( $D G G E$ ) of polymerase chain reaction ( $P C R$ )-amplified fragments of exon 9 of the presenilin 1 (PS-1) gene. The numbers on the left side denote the percentage range of $D G G E$. P rimer sequences were: upstream primer - 5' TTC-TAA-ATA-TTA-GAG CTG 3'; downstream primer - 5' GC clamp-GAT-AAT-GTAGCT-ACC-TA A-AG G 3'. Clear-cut migration abnormalities are visible for two patients (one of the samples was loaded twice), both affected individuals from different families, marked with arrows at the bottom of the gel. Figure $\mathbf{1 b} D$ irect DNA sequencing of PCR-amplified fragment of exon 9 from the two patients and normal control. The arrow points to the position of the heterozygous mutation; the order of loading is A C G T from left to right three families were identified as carriers of two distinct mis-sense mutations in PS-1. O ne mutation, G lu120Lys, was found in a Jewish A shkenazi family with early onset $A D$ accompanied by seizures. ${ }^{16} A$ nother mutation, G lu318G ly, was found in two Jewish families from different ethnic backgrounds, A shkenazi (Romanian) and M oroccan. This mutation was previously reported in one German family. ${ }^{11}$ No mutations were found either within exons 16 and 17 of the A PP gene, nor was the predominant PS-2 mutation ( $N 1411$ ) detected in any sample.

L ow rates of PS-1 mutations were found in I sraeli A D patients: for the familial cases mutation rate was $7.4 \%$ (2/27) and for the sporadic cases 4.5\% (1/22). In all mutation carriers disease manifestations started before the age of 60 years. This low rate of PS-1 mutation may stem from several causes. First, the phenotypic ascertainment of AD may have been erroneous, since no histopathological proof of the diagnosis is available. However, a unidirectional error in diagnosis of $A D$ by independent experienced physicians, in three medical centres, is highly unlikely. Secondly, the definition of 'familial' AD cases might have been too lax. Given the J ewish I sraeli reality of an immigrant population, with truncated families because of the holocaust, and extrapolating from other inherited predispositions, it is acceptable to designate these individuals as FA D.

Lastly, the possibility that existing mutations may have escaped detection seems unlikely given the specificity and sensitivity of DGGE, ${ }^{21}$ and its proven ability to identify known and novel mutations in the A PP and PS-1 genes. Thus it seems that the paucity of mutations detected in our patients truly reflects a low

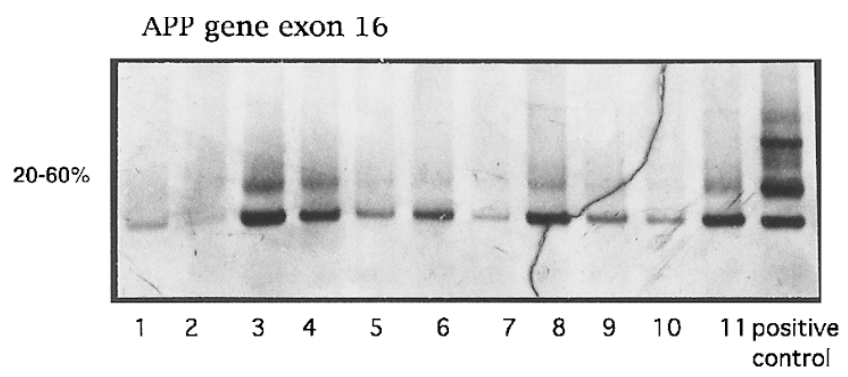

Figure 2 D enaturing gradient gel electrophoresis ( $D G G E$ ) of polymerase chain reaction (PCR)-amplified fragments of exon 16 of the APP gene. The numbers on the left side denote the percentage range of $D G G E$. The numbers below indicate patients' number. Positive control (C) is DNA amplified from patient with a known mutation in exon 16 (K 670N/M 671L). ( $G$ enerously supplied by D r L L annfelt, Huddinge H ospital, Stockholm, Sweden) 
occurrence rate. It is possible that mutations exist in the gene regions which were not analysed; the non-coding exons of the PS-1 gene, the other exons of the APP gene, promotor and regulatory regions.

In summary, the majority of FA D and sporadic, early onset $A D$ cases in Israel do not display mutations within the PS-1, APP or PS-2 genes, despite the adequacy of the mutation detection technique used. This may indicate the existence of other gene loci responsible for $A D$ predisposition in Jewish Israeli families with AD. Moreover, a single mutation, Glu318Gly, seems to occur in ethnically diverse patients, perhaps indicating the significant role that this residue plays in protein function.

\section{Acknowledgements}

This work was performed in partial fulfilment of the requirements for the $\mathrm{PhD}$ degree of $\mathrm{H}$ aike $\mathrm{R}$ eznik-Wolf from the Sackler School of M edicine at Tel-A viv U niversity

\section{References}

1 Liddell MB, Malcolm BL, Bayer AJ, O wen MJ: No evidence that common allelic variation in the A myloid Precursor Protein (APP) gene confers susceptibility to A Izheimer's disease. Hum M ol G enet 1995; 4: 853-858.

2 T sai M S et al: A polipoprotein E : risk factor for A Izheimer disease. A mer J H um G enet 1994; 54: 643-649.

3 Goate A et al: Segregation of mis-sense mutation in the amyloid precursor protein gene with familial A Izheimer's disease. Nature 1991; 349: 704-706.

4 A xelman $K$, Basun $H$, Winblad B, Lannfelt L: A large Swedish family with Alzheimer's disease with a codon $67 / 672$ amyloid precursor protein mutation. A rch Neurol 1994; 51: 1193-1197.

5 Peacock ML et al: Novel amyloid precursor protein gene mutation (codon $665 \mathrm{ASP}$ ) in a patient with late-onset A Izheimer's disease. A nn Neurol 1994; 35: 432-438.

6 Van Broeckhoven C: M olecular genetics of A Izheimer disease: identification of genes and gene mutations. E ur Neurol 1995a; 35: 8-19.

7 Sherrington $\mathrm{R}$ et al: Cloning of a gene bearing mis-sense mutation in early-onset familial Alzheimer's disease. Nature 1995; 375: 754-760.
8 Cruts $M, H$ endriks L, Van B roechoven C: The presenilin genes: a new gene family involve in A lzheimer disease pathology. H um Mol G enet 1996; 5: 1449-1455.

9 Van Broeckhoven C: Presenillins and A Izheimer disease. Nature Genet 1995b; 11: 230-232.

$10 \mathrm{H}$ utton $\mathrm{M}$ et al: Complete analysis of the presenilin 1 gene in families with early onset A Izheimer's disease. N euroreport 1996; 7: 801-805.

11 Sandbrink $R$ et al: M is-sense mutations of the S182/PS1 gene in G erman early-onset A Izheimer's disease patients. A nn Neurol 1996; 40: 265-266.

12 B oteva $\mathrm{K}$ et al: Mutation analysis of presenilin 1 gene in A Izheimer's disease. $L$ ancet 1996; 347: 130-131.

$13 \mathrm{~K}$ amino $\mathrm{K}$ et al: Three different mutations of presenilin 1 gene in A lzheimer's disease families. N eurosci L ett 1996; 208: 195-198.

14 Levy-L ahad $E$ et al: Candidate gene for the chromosome 1 familial A Izheimer's disease locus. Science 1995; 269: 973-977.

15 R ogaev EI et al: Familial A Izheimer's disease in kindreds with mis-sense mutations in a gene on chromosome 1 related to the Alzheimer's disease type 3 gene. Nature 1995; 376: 775-778.

16 Reznik-Wolf $H$ et al: A novel mutation of presenilin 1 in familial A Izheimer disease in I srael detected by denaturing gradient gel electrophoresis. Hum G enet 1996; 98: 700-702.

17 K hachaturian ZS: D iagnosis of A Izheimer's disease. A rch Neurol 1985; 42: 1091-1105.

18 Korczyn A D: The clinical differential diagnosis of dementia: concept and methodology. Psychiatr Clin N Amer 1991; 14: 237-251.

19 MCKhann $G$ et al: Clinical diagnosis of Alzheimer's disease: Report of the NINCDS-ADRDA work group. Neurology 1984; 34: 939-944.

20 Lerman LS et al: Sequence-determined DNA separations. A nnu Rev Biophys Bioeng 1984; 13: 399-423.

21 M yers R M , Fischer SG, L erman LS, M aniatis T: N early all single base substitutions in DNA fragments joined to a GC clamp can be detected by denaturing gradient gel electrophoresis. N ucl A cid R es 1985; 13: 3131-3145.

22 Syvänen AC, A alto-Setälä K, Kontula K, Soderlund $H$ : Direct sequencing of affinity-captured amplified human DNA application to the detection of apolipoprotein $E$ polymorphism. FEBS L ett 1989; 258: 71-74.

23 Mullan $M$ et al: $A$ pathologic mutation for probable A Izheimer's disease in the A P P gene at the $\mathrm{N}$-terminus of $\beta$-amyloid. Nature $G$ enet 1992; 1: 345- 347.

24 D uff $K$ et al: Increased amyloid $\beta 4 a 2(43)$ in brains of mice expressing mutant presenilin 1 . Nature 1996; 383: 710-713. 